Jurnal Agro 7(2), 2020

\title{
WATER SAVING TECHNOLOGY PACKAGE TO IMPROVE SHALLOT PRODUCTIVITY FOR SMALLHOLDER FARMERS IN EASTERN INDONESIA
}

\section{PAKET TEKNOLOGI HEMAT AIR UNTUK MENINGKATKAN HASIL BAWANG MERAH BAGI PETANI KECIL DI INDONESIA TIMUR}

\author{
Ahmad Suriadi ${ }^{*}$, Lia Hadiawati, Moh. Nazam \\ Balai Pengkajian Teknologi Pertanian (BPTP) Nusa Tenggara Barat \\ Jalan Raya Peninjauan Narmada Lombok Barat Nusa Tenggara Barat Indonesia \\ *Correspondence : ahmadsuriadi@pertanian.go.id
}

Accepted : $19^{\text {th }}$ November 2019 / Approved: 07 ${ }^{\text {th }}$ Novembe 2020

\begin{abstract}
Dryland usage for shallot cultivation is very potential in West Nusa Tenggara (NTB) Province Indonesia. However, its utilization is faced with various obstacles such as soil low fertility, limited water availability, and high pest and disease attacks. Currently, farmers apply flood and furrow irrigation methods for shallot cultivation in NTB Province, which may not suitable on dryland, especially on coarse texture soils. The purpose of this study was to obtain a package of watersaving technology to increase the productivity of shallots in the dryland of NTB. There were three treatments of technology packages tested laid as Randomized Block Design: A (Trichoderma sp., bio-urine liquid fertilizer, sprinkler irrigation; B (bio-urine liquid fertilizer, furrow irrigation); and $C$ (farmer practice), involving farmer group members from planning to evaluating for the technology package that being tested. The amount of water used was measured using a water meter. The results showed that package A had achieved the highest shallot yield at 31.6 tons ha${ }^{1}$, which was $14 \%$ and $45 \%$ higher compared to package B and C, respectively. Package A was also able to save water irrigation for $62.1 \%$ and $95.8 \%$ compared to package B and C, respectively. Thus, sprinkler irrigation not only can increase shallot yield but also better in saving water irrigation.
\end{abstract}

Keywords: dryland, productivity, shallot, technology package, water saving

\section{ABSTRAK}

Penggunaan lahan kering untuk budidaya bawang merah di Nusa Tenggara Barat sangat potensial. Namun hal tersebut terkendala oleh beberapa masalah seperti rendahnya kesuburan tanah, terbatasnya air irigasi, dan tingginya gangguan hama dan penyakit. Saat ini, petani di NTB mengairi tanaman bawang merah dengan cara direndam atau leb yang belum tentu sesuai dengan kondisi lahan kering terutama pada tanah dengan tekstur berpasir. Tujuan dari penelitian ini adalah untuk mendapatkan paket teknologi hemat air yang dapat meningkatkan hasil dan pendapatan budidaya bawang merah di lahan kering. Ada tiga perlakuan paket teknologi yang ditata dengan rancangan acak kelompok yaitu A (Trichoderma sp., pupuk organik cair bio-urine, dan irigasi curah); B (pupuk organik cair bio-urine, dan pengairan leb), dan paket $C$ (cara petani: pengairan leb). Penelitian ini melibatkan petani mulai dari perencanaan sampai 
evaluasi paket teknologi yang diujikan. Hasil penelitian menunjukkan bahwa paket $A$ menghasilkan produksi tertinggi sebesar $31,6 \mathrm{t} \mathrm{ha}^{-1}$, atau $14 \%$ dan $45 \%$ ebih tinggi dari paket $\mathrm{B}$ dan C. Paket A juga mampu menghemat air irigasi sebanyak $62,1 \%$ dan $95,8 \%$ dibandingkan dengan paket $\mathrm{B}$ dan $\mathrm{C}$. Dengan demikian, penggunaan irigasi curah mampu meningkatkan hasil dan menghemat air irigasi.

Kata kunci: bawang merah, hemat air, lahan kering, paket teknologi, produktivitas

\section{INTRODUCTION}

West Nusa Tenggara (NTB) province is the third-largest national producer of shallots (Allium ascalonicum L.) with harvest area of 11,518 ha. The largest shallot cultivation area is located in Bima District for 8,027 ha followed by East Lombok District for 1,156 ha (Badan Pusat Statistik, 2015). Although the potential land for the development of shallots cultivation is huge up to 118,241 ha, but currently only $6.32 \%$ has been used (Nazam et al., 2012).

Extensification of shallots is increasing from year to year due to the surge of demand and the profitable selling price for farmers. The expansion of shallot cultivation area mostly occupies dryland which covers more than $80 \%$ of the total land of NTB (Badan Pusat Statistik, 2015). The development of shallot cultivation in dryland is one of the strategic policy to reduce poverty in NTB because most of the poverty live in dryland areas moreover their livelihood relies on agricultural activities.

Quantitatively, dryland utilization is very potential and strategic policy in supporting agricultural development (Mulyani \& Hidayat, 2009). However, qualitatively, the utilization has faced various obstacles both technically, socially, and economically (Benzinger et al., 2006; Jensen et al., 2003; Ma'shum, 1997). Constraints in the usage of the dryland include limited water availability, relatively low soil fertility, also short and erratic wet season periods (Debaeke \&
Aboudrare, 2004). These conditions affect plant growth and plant production (Abdurachman et al., 2008; Mulyani \& Hidayat, 2009; Utomo, 2002). Most of the dryland conditions in NTB are characterized by a dry climate, namely the D3 climate type (3-4 wet months and 4-6 dry months), D4 climate type (3-4 wet months and $>6$ dry months), E3 type ( $<3$ wet months, 4- 6 dry months), and E4 climate types $(<3$ wet months and $>6$ dry months) (Oldeman et al., 1980).

The main constraints on the development of shallot cultivation on dryland are water scarcity also pests and diseases attack. Furthermore, farmers always irrigate shallots by furrow and flood irrigation methods. This causes waste of water and labour. One method of irrigation that quite efficient to be used is sprinkler irrigation, because this method can save water, besides the water irrigation can be applied in accordance to the needs of plants accurately (Li \& Rao, 2003; Undang, 2004). However, the sprinkler irrigation system has not been studied in detail and demonstrated at the farmer level. This can be seen where rarely farmers used a sprinkler to irrigate the shallots. In addition, the farmers irrigate shallot plants not based on crop needs and the right time but they irrigated every day to keep the soil moist. Thus, it is very necessary to study and demonstrate an effective and efficient irrigation system that is economically profitable, socially acceptable, and technically easy to do. 
Components of water-saving technology of shallot cultivation sufficiently available from the results of research elsewhere (Roy, 2014; Sumbayak \& Susila, 2018; Vickers et al., 2015; Yenus, 2013). However, most of these components have not been assembled and combined in the form of technological packages that are ready to be adopted by farmers at the field level. So far there is no local-specific technology package that considers the amount of irrigated to be applied on shallot cultivation in dryland. With the technology package, the shallots productivity can be increased by at least $20 \%$. The purpose of this study was to determine the productivity of shallot with a water-saving technology package in the dryland of NTB.

\section{MATERIAL AND METHODS}

The experiment was conducted from June to August 2018 at Labuhan Lombok Village, Pringgabaya sub-district, East Lombok
District $(-8.51157,116.65475)$. The site has been regarded as a dryland and semi-arid climate agroecosystem and centre of shallot production in NTB.

The technology package studied consisted of three packages as treatment (Table 1). Package A was a technology package from the results of experimental technology components carried out in 2017, especially the use of Trichodermasp., biopesticides, bio-urine, sprinkler irrigation, and timing of irrigation with soil moisture testing equipment. Package $B$ was almost similar to package $A$ but with furrow irrigation and without Trichoderma sp., and package $C$ was conventional farmers' practice. The experiment was conducted through participatory research approach, which was carried out on farmers' land basis by fully involving farmers and extension agents starting from the planning stage until evaluating the performance of each technology packages.

Table 1 Package of water-saving technologies for shallot cultivation

\begin{tabular}{|c|c|c|c|}
\hline \multirow{2}{*}{$\begin{array}{l}\text { Components of } \\
\text { Package }\end{array}$} & \multicolumn{3}{|c|}{ Packages of Technology } \\
\hline & Package A & Package $\mathrm{B}$ & Package C \\
\hline Land preparation & Complete tillage & Complete tillage & Complete tillage \\
\hline Seed quality & Certificated seed & Certificated seed & Certificated seed \\
\hline Seed treatment & Yes & Yes & No \\
\hline Fertilizer applied ha-1 & $\begin{array}{l}\text { Compos }=10 \mathrm{t} \mathrm{ha}^{-1}+\mathrm{SP} \\
36=150 \mathrm{~kg} \mathrm{ha}+1+\mathrm{ZA}= \\
250 \mathrm{Kg}+\mathrm{NPK}=250 \mathrm{~kg}+ \\
\text { Urea }=100 \mathrm{~kg} \mathrm{ha}^{-1}\end{array}$ & $\begin{array}{l}\text { Compos }=10 \mathrm{t} \mathrm{ha}^{-1}+\mathrm{SP} \\
36=150 \mathrm{~kg} \mathrm{ha}-1+\mathrm{ZA}=250 \\
\mathrm{Kg}+\mathrm{NPK}=250 \mathrm{~kg}+ \\
\text { Urea }=100 \mathrm{~kg} \mathrm{ha}^{-1}\end{array}$ & $\begin{array}{l}\text { Farmers practices } \\
\left(\mathrm{SP} 36=250 \mathrm{~kg} \mathrm{ha}^{-1}+\right. \\
\mathrm{ZA}=350 \mathrm{~kg} \mathrm{ha}^{-1}+\mathrm{NPK} \\
=300 \mathrm{~kg} \mathrm{ha}^{-1} \text { and urea= } \\
100 \mathrm{~kg} \mathrm{ha}^{-1}\end{array}$ \\
\hline Biopesticide & Trichoderma sp. & No biopesticide & No biopesticide \\
\hline Weeding & As condition & As condition & As condition \\
\hline Irrigation & Sprinkler & Furrow & Furrow \\
\hline Time of irrigation & Using soil moisture kit & Using soil moisture kit & When the soil dry \\
\hline Pest and disease & $\begin{array}{l}\text { Integrated pest and } \\
\text { diseases control }\end{array}$ & $\begin{array}{l}\text { Integrated pest and } \\
\text { diseases control }\end{array}$ & $\begin{array}{l}\text { Every } 2 \text { days upto } \\
\text { harvest }\end{array}$ \\
\hline Bio-urine & $12 \%$ for $4 x$ applied & $12 \%$ for $4 x$ applied & No bio-urine \\
\hline
\end{tabular}

Each farmer applied three technological packages for at least 0.2 ha of each. Thus, the amount of land used in this experiment was about 2 ha. Data about the amount of water given during the plant growth period were recorded to determine water efficiency and 
water savings in each irrigation treatment using a water meter. For packages $\mathrm{A}$ and $\mathrm{B}$, irrigation water was applied when soil moisture content had reached $14.8 \%$, which was measured using a soil moisture test. The soil moisture content limit was based on $20 \%$ of available water that was still present in the soil before reaching a permanent wilting point. For package $\mathrm{C}$, irrigation water was applied based on farmer practice, still the amount and times for irrigation were recorded.

Every activity on shallot cultivation in the field was recorded in the form of a farm record-keeping for each farmer cooperators. This was done to ensure that all of the packages of technology were applied by farmer co-operators.

Agronomical parameters observed in this study included plant height and numbers of leaves observed using 15 plant samples at 20 days after sowing (DAS), 40 DAS and at harvesting time; fresh and dry weight of yield. Data were analysed using T-test by comparing treatment $A B, A C$, and $B C$.

\section{RESULTS AND DISCUSSION}

\section{Climate and water irrigation}

The Sandubaya site of Labuhan Lombok Village, Pringgabaya District is regarded as a dryland and semi-arid agroclimatic zone. This is indicated by the total annual rainfall which is less than $1500 \mathrm{~mm}$ per year and included in climate types of $\mathrm{D}$ and $\mathrm{E}$ (Oldeman et al., 1980). The average annual rainfall for the last 17 years in the region is $640 \mathrm{~mm}$. The average monthly rainfall for 17 years (2000 - 2016) in the region is presented in Figure 1. The wet months of the study area are only three months from December to February meanwhile the rest are dry months.

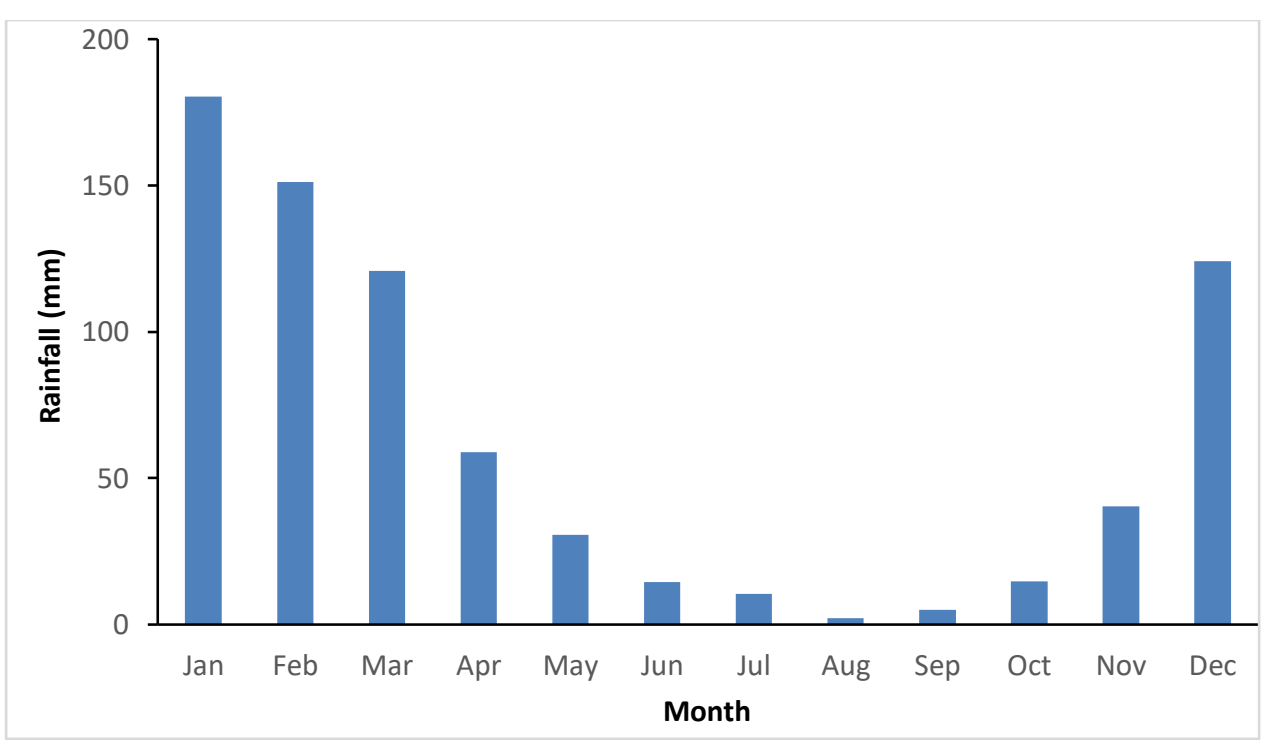

Figure 1 Average monthly rainfall for 17 years (2000-2016) at Pringgabaya East Lombok

The topography of the Sandubaya region is relatively flat, dominated by Entisols soil type with sandy to sandy loam texture. Besides relying on rainwater, Sandubaya also uses ground water (pumping wells) for irrigation called P2AT.
In the Pringgabaya Subdistrict area, there are 72 P2ATs with varying debits of around 10-20 $\mid \mathrm{s} \mathrm{s}^{-1}$. P2AT wells are managed by a groundwater user farmer association (P3AT). Irrigation costs using P2AT wells vary from Rp. 30,000-35,000 per hour. One ha of land 
requires around 20 hours to irrigate the plants.

\section{Land characteristic}

Land characteristics of the site are shown in Table 2. In general, the nutrient contents of phosphor and potassium were high, while nitrogen $(\mathrm{N})$ status was low. Soil $\mathrm{pH}$ was in the range of neutral to slightly alkaline. The ability of soil to hold water was quite low due to the very low content of clay and organic matter. The percentage of clay at the site was about $10 \%$ in the top layer of $0-10 \mathrm{~cm}$ and decreased to $6 \%$ at soil depth of $20-40 \mathrm{~cm}$. Thus, the furrow irrigation method may be less suitable for this location. However, the reality in the field farmers always apply furrow and flooded irrigation for shallot cultivation.

Table 2 Soil properties at Sandubaya site

\begin{tabular}{|c|c|c|c|c|c|c|c|c|c|c|c|}
\hline \multirow{2}{*}{$\begin{array}{l}\text { Soil } \\
\text { layers }\end{array}$} & $\mathrm{pH}-\mathrm{H} 20$ & $\mathrm{pH}-\mathrm{kCl}$ & $\mathrm{EC}$ & N Total & Organic-C & $\begin{array}{l}\mathrm{P}_{2} \mathrm{O}_{5} \\
\text { Olsen }\end{array}$ & CEC & K & $\mathrm{N}$ & $\mathrm{Ca}$ & $\mathrm{Mg}$ \\
\hline & \multicolumn{2}{|c|}{$\mathrm{pH}$-meter } & $\mu \mathrm{S} \mathrm{cm} \mathrm{cm}^{-1}$ & $\%$ & $\%$ & ppm & $\mathrm{cmol}$ & \multicolumn{4}{|c|}{$\mathrm{cmol} \mathrm{kg}^{-1}$} \\
\hline $0-10$ & 7.95 & 6.52 & 0.140 & 0.250 & 0.807 & 58.87 & 18.83 & 2.73 & 3.70 & 13.63 & 3.60 \\
\hline $10-20$ & 7.91 & 6.51 & 0.103 & 0.167 & 0.602 & 52.30 & 16.37 & 0.77 & 1.77 & 8.73 & 3.13 \\
\hline $20-40$ & 7.97 & 6.71 & 0.170 & 0.120 & 0.273 & 41.80 & 19.40 & 1.33 & 2.03 & 12.43 & 3.57 \\
\hline \multirow[t]{2}{*}{$\begin{array}{l}\text { Soil } \\
\text { layers }\end{array}$} & \multicolumn{3}{|c|}{ Texture (\%) } & $\begin{array}{c}\text { Bulk } \\
\text { Density }\end{array}$ & WP & \multicolumn{3}{|r|}{ AW } & \multicolumn{2}{|c|}{$\begin{array}{l}\text { Infiltration } \\
\text { rate }\end{array}$} & \\
\hline & sand & silt & clay & $\begin{array}{l}\text { gr per } \\
\mathrm{cm}^{3}\end{array}$ & \multicolumn{4}{|c|}{$\%$ volume } & \multicolumn{2}{|c|}{$\mathrm{cm} \mathrm{h}^{-1}$} & \\
\hline $0-10$ & 57 & 33 & 10 & 1.08 & 11.29 & \multicolumn{2}{|c|}{29.19} & 17.90 & \multicolumn{2}{|c|}{5.38} & \\
\hline $10-20$ & 56 & 36 & 9 & 1.1 & 13.23 & \multicolumn{2}{|c|}{28.83} & 15.60 & \multicolumn{2}{|c|}{6.02} & \\
\hline $20-40$ & 54 & 40 & 6 & 1.08 & 10.98 & \multicolumn{2}{|c|}{24.93} & 11.95 & \multicolumn{2}{|c|}{4.98} & \\
\hline
\end{tabular}

Note: $\mathrm{EC}=$ electrolyte conductivity; $\mathrm{CEC}=$ cation exchange capacity; $\mathrm{WP}=$ wilting point; $\mathrm{UL}=$ upper limit and $\mathrm{AW}=$ available water content

\section{Agronomic parameters and yield of shallot}

Plant height during the growth of shallots at various technological packages applied is shown in Figure 3. In general, the performance of shallot height at 20 days after sowing (DAS) was not significantly different for package $A$ and package $B$, except package $C$, where it was higher than other packages. At 40 DAS, the height of shallot at package $A$ was higher than the others, although this was not significantly different with package B but significantly different from package C. Furthermore, at 60 DAS or harvest stage, plant height of shallot was not significantly different at all packages. It was observed that shallot height at 40 DAS was shorter than at 20 DAS. This was due to manually cutting leaves that were attacked by caterpillar pests. Yoo et al. (2019) reported that the the bulb weight of short-day onions plants was either reduced or increased by cutting leaves. 


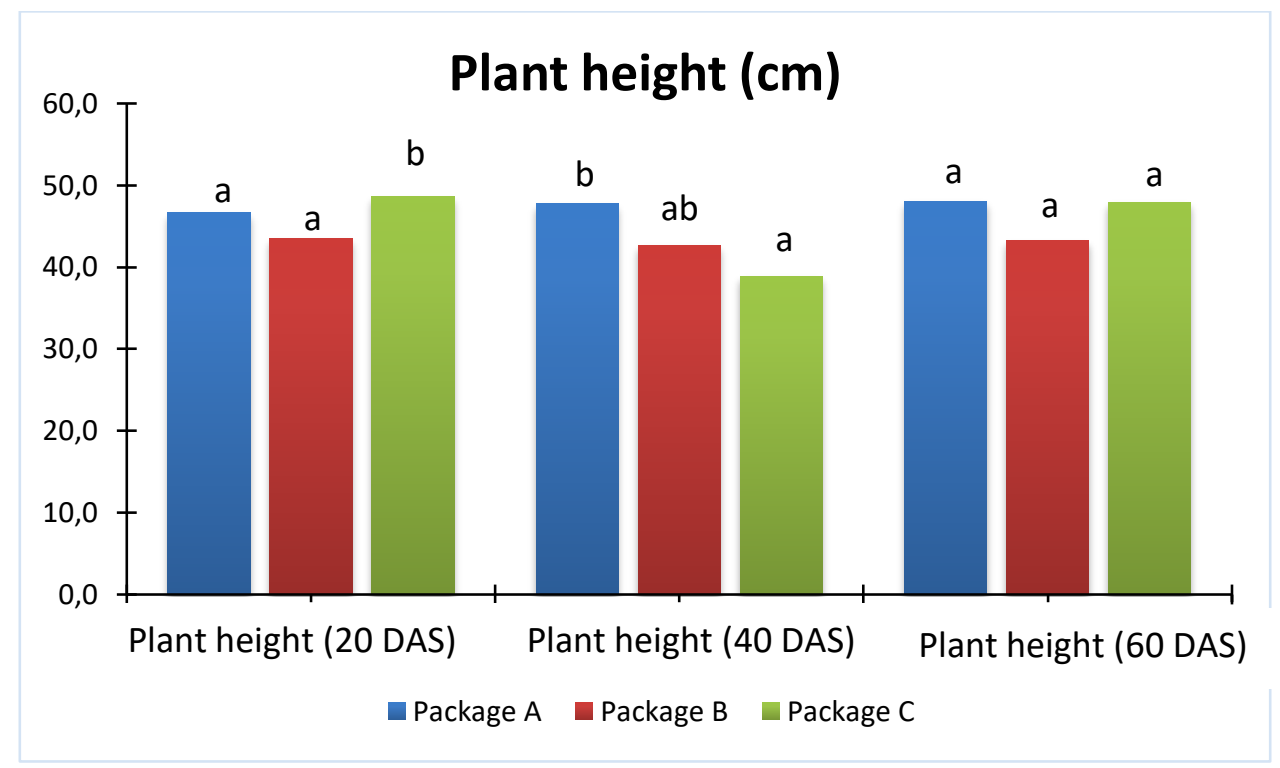

Figure 2. plant height of shallot at various package of technology

The effect of the technology packages on leaves number during growth period of shallot is shown in Figure 3. In general, the number of leaves of shallot increased along with the growth period. The number of leaves on package $A$ at 20 and 60 DAS was higher than other packages, although this was not significantly different with package $B$, indicating that technology package $A$ had given good influence in increasing growth of shallot compared with farmer practices. The number of leaves at package $C$ treatment was less than the other packages. The leaves of shallot at package $C$ was very dry at the time of harvest compared to the other packages. While leaves of shallot at package $A$ and package $B$ were still look green.

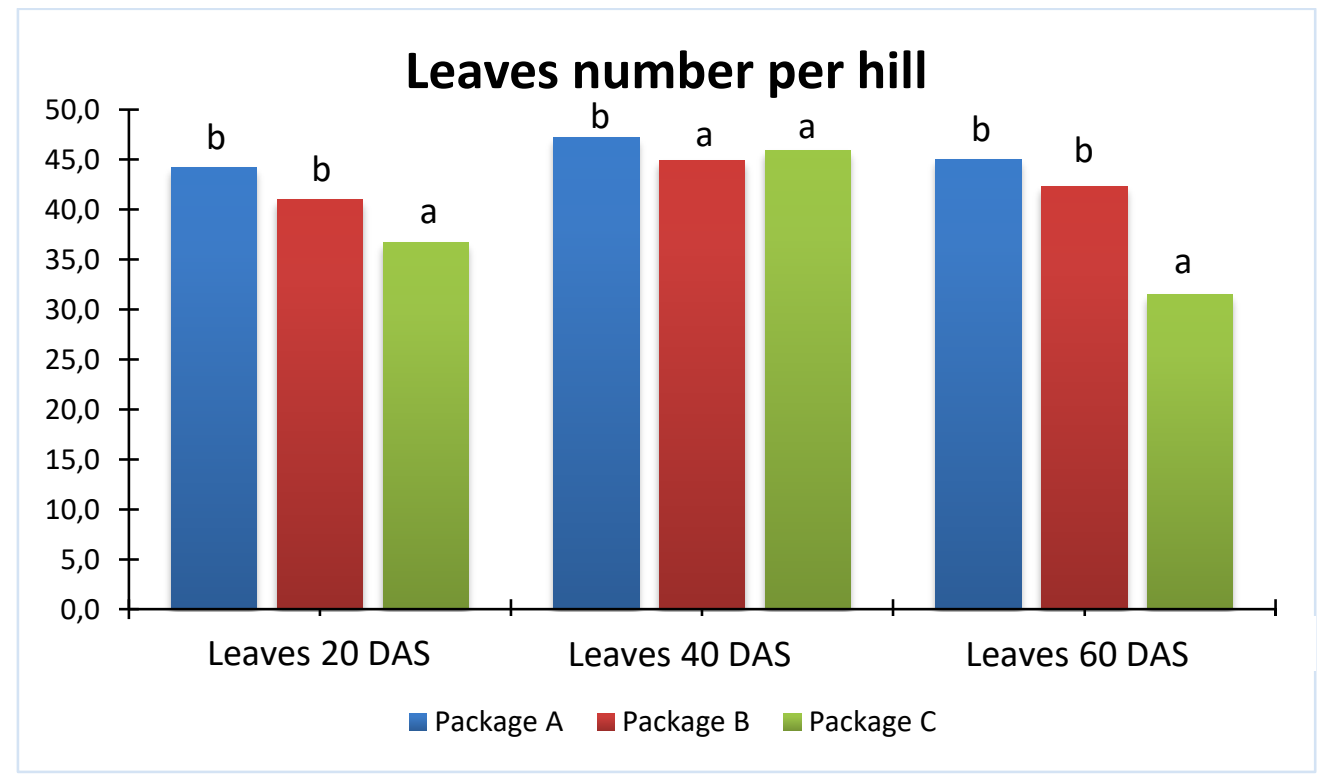

Figure 3 Influence of saving water package technology on leaves number of shallot. 
One of yield parameters that determines the productivity of shallots is number of bulbs. The more bulbs, the higher yield of shallots obtained. Variation of bulb number of shallots for whole technology packages is shown in Figure 4. Generally, the number of bulbs per square meter for each technology package applied was not significantly different. This indicates a uniformity of growth and population at all packages technology applied. However, there was a tendency of shallot bulb increase at package A compared to packages B and C.

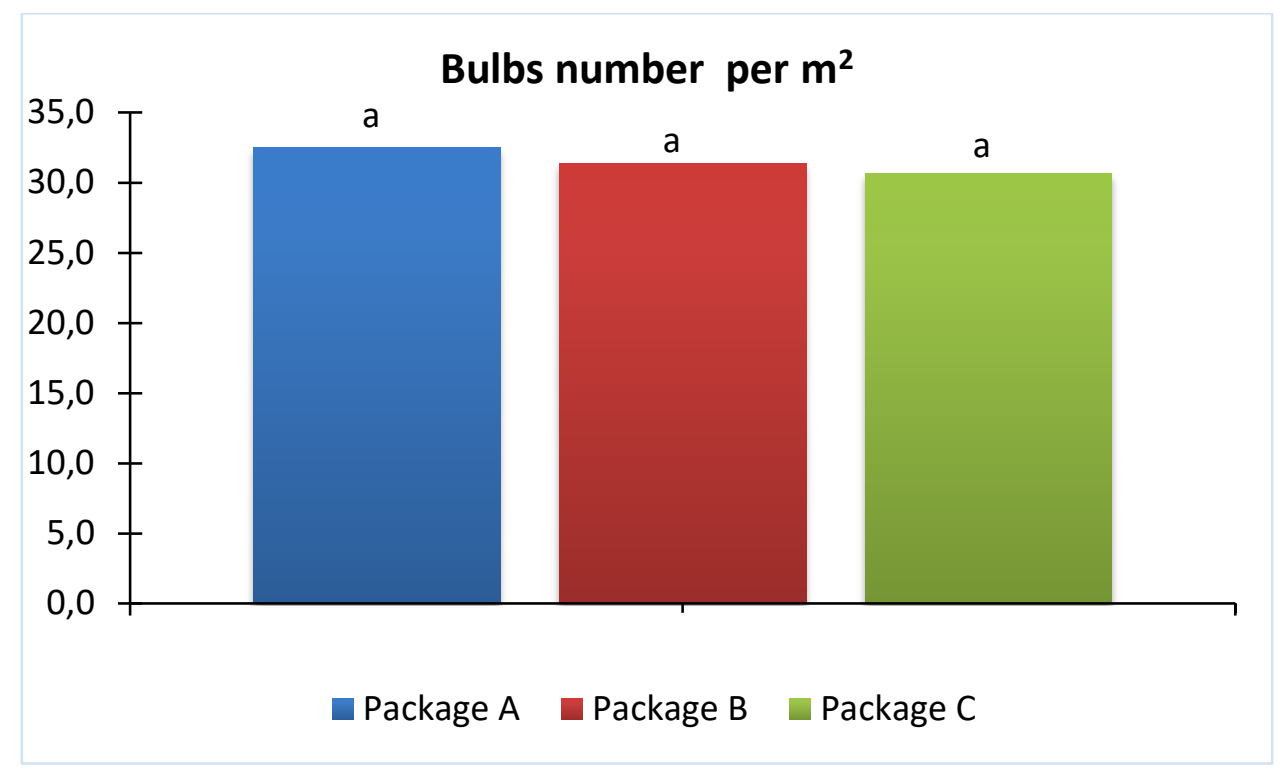

Figure 4 Influence of water-saving package technology on number of shallot bulbs.

Variation of shallot yield on wet and dry weights is shown in Figure 5. In general, the yield of shallots was quite varied due to the implementation of the technology package. The highest shallot yield was found at package $A$ technology followed by package $B$ and the lowest was package $C$ (farmers practice). The technology of package $A$ increased yield of shallots by 31.6 tons ha ${ }^{-1}$ (fresh weight), it was $14 \%$ and $45 \%$ higher compared to package $B$ and package $C$, respectively. Thus, package $A$ which was water-saving technology for shallot was quite feasible to be applied by farmers around the study site. The yield of shallot in dry conditions also showed a similar trend to wet weight. In dry conditions, the technology of package $A$ increased yield of shallot by $10 \%$ compared to package B and $45 \%$ compared to package $C$. 


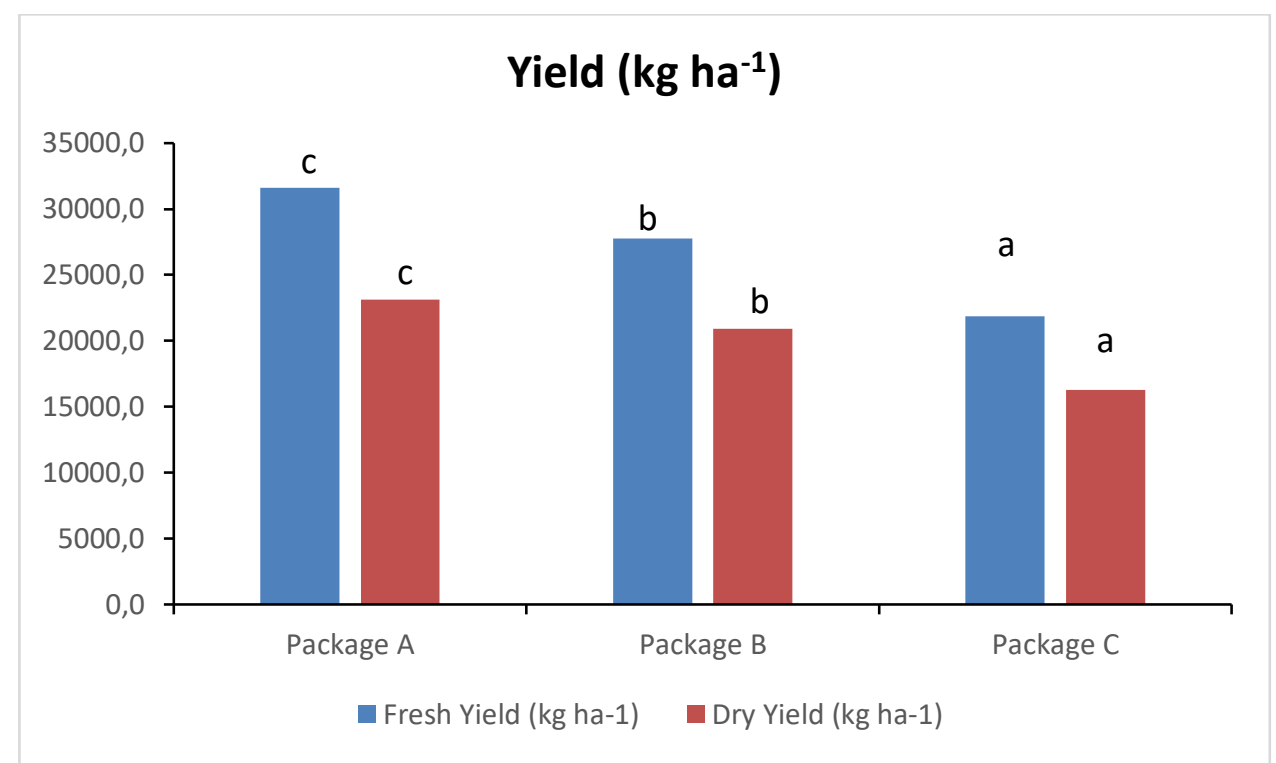

Figure 5 Yield of shallot influenced by water-saving technology packages in dryland of NTB

The amount of water irrigation

The amount of water irrigation used during shallot plant growth period (63 days) for each technology package is shown in Table 3.

Table 3 Water irrigation used at various shallot growth stages due to water-saving technology packages

\begin{tabular}{lcccc}
\hline \multirow{2}{*}{ Growth stages } & $\begin{array}{c}\text { Stage duration } \\
\text { (days) }\end{array}$ & \multicolumn{3}{c}{ Irrigation used (mm) } \\
\cline { 3 - 5 } & & Package A & Package B & Package C \\
\hline Sowing time & 15 & 84.0 & 64.0 & 64.0 \\
Early stage & 25 & 95.4 & 119.0 & 147.0 \\
Optimum growth & 15 & 79.7 & 199.0 & 246.0 \\
Maximum growth & 8 & 20.2 & 119.0 & 147.0 \\
Ripening & 63 & $\mathbf{3 4 8 . 8}$ & $\mathbf{5 6 5 . 3}$ & $\mathbf{6 8 3 . 0}$ \\
Total & & & 62.1 & 95.8 \\
Irrigation efficiency (\%) & & $3,725,000$ & $6,037,000$ & $7,294,000$ \\
Irrigation cost (Rp.) & & & & \\
\hline
\end{tabular}

Package A amounted to $348.8 \mathrm{~mm}$ as the lowest value than other packages. Debit of pumping well used to irrigate shallot was 7.9 $1 \mathrm{~s}^{-1}$ and duration required for irrigation was 22.5 hours per hectare. Package A (sprinkler) was able to save water up to $62.1 \%$ and 95.8\% compared to package B (furrow irrigation) and packages $C$, respectively. Undang (2004) stated that in coarsetextured soil, the efficiency of water use with the sprinkler method was twice as high as surface water irrigation.

\section{CONCLUSION}

1. Water-saving technology package for shallot in dryland using sprinkler irrigation increased productivity of shallots by $31.6 \mathrm{t} \mathrm{ha}^{-1}$, which was $14 \%$ and $45 \%$ higher compared to package $B$ 
(furrow irrigation) and package $\mathrm{C}$ (farmer practice), respectively.

2. The amount of water used during the growth of shallots for package A was $348.8 \mathrm{~mm}$ which was $62.1 \%$ and $95.8 \%$ lower than package $B$ and $C$, respectively. The irrigation cost of package A was less than the others, which was more efficient by $15.8 \%$ to package $B$ and $30.4 \%$ to package $C$.

3. The development of a water-saving technology package is very promising. Therefore, socialization and demonstration plots in several regions are very necessary to disseminate and adopt the technology package by the farmers. However, this technology may need financial analysis in order to meet economic feasibility.

\section{ACKNOWLEDGEMENT}

This study was fully funded by the SMARTD. The authors are also thankful to Mr. Rasyid Ridho and Mr. Suparjan who were helping us in the field during the experiment conducted.

\section{REFERENCES}

Abdurachman, A., Dariah, A., \& Mulyani, A. (2008). Strategi dan teknologi pengelolaan lahan kering mendukung pengadaan pangan nasional. Jurnal Litbang Pertanian, 27(2), 43-48.

Badan Pusat Statistik, B. (2015). NusaTenggara Barat Dalam Angka Badan Pusat Statistik Republik Indonesia.

Benzinger, M., Setimle, P. ., Hodson, D., \& Vivek, B. (2006). Breeding for improved abiotic stress. Agricultural Water Management, 80, 212-224.
Debaeke, P., \& Aboudrare, A. (2004). Adaptation of crop management to water-limited environments. European Journal of Agronom, 21, 433-446.

Jensen, J. ., Bernhard, R. ., Hansen, H., McDonagh, J., Moberg, J. ., Nielsen, N. E., \& Nordbo, E. (2003). Productivity of maize based cropping systems under varios soil water nurtient management strategies in semi-arid, Alfisols enviroenment in East Africa. Agricultural Water Management, 59, 217-237.

Li, J., \& Rao, M. (2003). Field evaluation of crop yield as affected by nonuniformity sprinkler-applied water and fertilizers. Agricultural Water Management, 59, 1-13. https://doi.org/10.1016/S03783774(02)00123-3

Ma'shum, M. (1997). Kemangkusan (Efficiency) Pemupukan dilahan kering (Makalah Disampaikan Pada Temu Aplikasi Paket Teknologi Pertanian Sub Sektor Tanaman Pangan Di Mataram 12-14 Maret 1997.).

Mulyani, A., \& Hidayat. (2009). Peningkatan kapasitas produksi tanaman pangan pada lahan kering. Jurnal Sumberdaya Lahan Pertanian, 3(2), 73-84.

Nazam, M., Suriadi, A., Zulhaedar, F., \& Hafid. (2012). Pewilayahan komoditas berdasarkan zona agroekosistem. In Laporan Pengkajian. Balai Pengkajian Teknologi Pertanian Nusa Tenggara Barat.

Oldeman, L. ., Las, I., \& Muladi. (1980). The Agroclimatic Map of Kalimantan, Irian Jaya, and Bali, West and East Nusa Tenggara. CRIA. Bogor. Indonesia. CRIA.

Roy, D. (2014). Effect of Irrigation at Different Growth Stages on Yield, Water Productivity and Seed 
Production of Onion (Allium cepa L. CV BARI Piaz-1). American Journal of Agriculture and Forestry, 2, 256. https://doi.org/10.11648/j.ajaf.20140 206.14

Sumbayak, R. D. L., \& Susila, A. D. (2018). Spray Hose Irrigation System Increased Yield of Polyethylene Mulched Shallot. Journal of Tropical Crop Science, 5(2), 49-54.

https://doi.org/10.29244/jtcs.5.2.4954

Undang, K. (2004). Prospek pengairan pertanaman semusim lahan kering. Jurnal Penelitian Dan Pengembangan Pertanian, 23(4), 12-20.

Utomo. (2002). Pengelolaan lahan kering untuk pertanian berkelanjutan. Seminar Nasional IV Pengembangan Wilayah Lahan Kering Dan Pertemuan IImiah Tahunan Himpunan IImu Tanah Indonesia Di Mataram, 27-28 Mei 2002.

Vickers, L., Grove, I., \& Monaghan, J. (2015). Soil type and irrigation affect onion yield and storability. Acta Horticulturae, 1091, 245-251. https://doi.org/https://doi.org/10.176 60/ActaHortic.2015.1091.30

Yenus, O. K. (2013). Effects of irrigation and nitrogen levels on bulb yield, nitrogen uptake and water use efficiency of shallot (Allium cepa var. ascalonicum Baker). African Journal of Agricultural Research, 8(37), 4637-4643. https://doi.org/10.5897/ajar12013.67 37

Yoo, K. S., Leskovar, D., Patil, B. S., \& Lee, E. J. (2019). Effects of leaf cutting on bulb weight and pungency of short-day onions after lifting the plants. Scientia Horticulturae, 257(June), 108720. https://doi.org/10.1016/j.scienta.2019 .10872 